\title{
Ciliary Body Disorder
}

National Cancer Institute

\section{Source}

National Cancer Institute. Ciliary Body Disorder. NCI Thesaurus. Code C35775.

Any disease or disorder of the ciliary body. 